Original Article

\title{
Swimming as an inclusion tool for autistic subjects
}

\author{
SALVATORE NAPOLITANO \\ University of Naples "Parthenope" - Department Physical Education and Wellness
}

Published online: November 24, 2017

(Accepted for publication November 15, 2017

DOI:10.7752/jpes.2017.s5256

\begin{abstract}
Autism, originally called Kaner Syndrome, is considered by the international scientific community as an ailment concerning cerebral function. A person affected by autism displays a significant decrease in social integration and communication. Aquatic motor activities involve a natural element (water) in a structured environment (public pool), according to a theoretic reference model and an organized methodology through phases, and uses cognitive, behavioral, and relational techniques and motor senses. Our research was carried out at the public pool of the commune of Santa Maria Capua Vetere where a group of ten subjects affected by autism from the ACFFADIR Association, have been practicing aquatic activities for two years, with biweekly meetings. During these activities, the pool is also attended by subjects who are not affected by any ailments and by athletes in training. The analysis of the research carried out through the systematic observation by the operators, the surveys of the teachers in the educational field, and the findings of family and social environment and the results of the surveys show given improvements on the social affective and relational level, and improvements regarding personal autonomy and self esteem. Such an activity can, therefore, be considered a valid tool to favor the insertion and the inclusion of subjects affected by autism into the social environment.

Keyword: Autism, aquatic activities, inclusion
\end{abstract}

\section{Introduction}

Autism, originally called Kaner Syndrome, is considered an ailment affecting cerebral functions, appearing in infant years, which causes deficiencies in many areas regarding development, such as learning to speak and interact with people, social interaction, difficulties regarding verbal and non verbal communication, bizarre and repetitive speech, inappropriate facial expressions and gestures, comprehensive difficulties, repetitive and "stereotyped" behavior and limited interests.

Such symptoms, now mentioned in an international list of illnesses, DSM IV (American manual of mental deficiencies, translated into Italian by Masson editors) and ICD 10 (international classification of illnesses) by the World Health Organization, are seen even before the age of three and persist throughout the subject's life, together with the natural changes that occur with the coming of age.

At the root of the syndrome we find different organic deficiencies that modern biochemical research has progressively individualized, but many experts agree on the involvement of genetic and environmental factors.

The prevalence of the syndrome regards one case in 500 born (Filipek PA et AA. Neurology 22 August 2000, pp. 468-79).

Autism is presents with the same frequency in all races, ethnicities and social classes, though males develop the disorder with a higher frequency of about 3-4 time more frequent than in females One of the most recognized theories (Folstein S., Rutter M: Infantile autism: a genetic of 21 twin pairs. - Journal of Child Psychology and Psychiatry 18, 297-321, 1977), is that which states that many children are born with a genetic predisposition to the disorder that can later be stimulated by environmental factors. Research indicates that some genes, in particular hereditary and spontaneous mutant genes of DNA play an important role in the development of autism. But there isn't only one gene to accuse, as others also contribute and greater the risk.

Considering the variables regarding each individual case study, studies and research related to this field have characterized a common ailment represented by problematic knowledge, use and knowledge of the body. Based on this evidence we can already attribute an important role to the motary instruction in the process of an autistic child, especially in the first evolutionary phase regarding an instructional program aimed especially to the development on the levels of: autonomy, relationships and the ability to communicate.

\section{Methods}

The aquatic environment is surely highly indicated in the carrying out of motary activities in various types of disabilities, when the activities are done as generic support or maintenance of motary functions, like in the cases of recuperation and conditioning of the locomotive and cardiovascular functions, and when it is used as therapeutic. 
In recent years, swimming has become very popular in children with autism. Water facilitates keeping their attention, divided and undivided, offering intense sensory stimulation, easing emotional aspects thanks to contained emotion, eases behavioral ailments (aggressiveness, stereotypes), greatens eye contact, favors social integration, stimulates desire and exploration, promotes the growth of self esteem when movement autonomy in the water is gained and stimulates coordination abilities.

Swimming techniques are used to reach therapeutic objectives and to successfully activate a fundamental process of socialization and integration with the group of peers.

If the autistic subject already has a good relationship with water, and good water abilities, follows instructions and is autonomous in his movements, he/she can be followed pool side: if the autistic subject is afraid of the water, the instructor will preside in the water and accompany him in his exploration of a small pool, so as to favor his abilities and create empathy and trust.

Motary water activities use a natural element (water) inside a structured environment (public pool), according to a theoretic model of referral and organized methodology through phases which uses technical, behavioral, relational cognitive, and motary senses

The main objective is that to bring the subject closer to and "meet" the water through recreational motary experiences and situations carried out at his own pace: we have worked on the familiarization with the environment and water abilities where the subject created a natural relationship with the water element, that allowed him to experiment new and different motary situations.

Another objective was that to favor the attendance in a social context, like that of a sports facility furnished as needed, and favoring social integration.

Our study was carried out at the public pool of Santa Maria Capua Vetere, with a group of 10 subjects, between 12 and 17, affected with autism belonging to "ACFFADIR" Association. They've been practicing for two years, with biweekly meetings during the months of September to July, with motary water activities carried out with an instructor 1:1 for 40 minutes each meeting. During such activities the swimming facility was also attended by normal subjects and athletes in training. The intervention is focused on the role of the instructor, a tutor enabling the necessary abilities, not only of motary ability, but also educational and relational, and the person who will accompany the subject at a steady pace in the project, individualized and in agreement with the families.

The activities were planned based on gradual progression, individualized towards the goal of the objectives mentions, and adaptable lesson by lesson according to the subject's needs, keeping in mind the occasional and monetary moments of discomfort.

At the beginning, an individualized relationship was created, in order to create an empathetic relationship sharing simple and clear rules. In this, the instructor was able to build a trusting relationship with the student, becoming a reference point, a teacher with whom his water training would be pleasant and stimulating. The best environmental aquatic settings were researched in order to stimulate motary expression through emotions, looking for limited manifestations of negative behavior associated with the disorder. The methodology saw the use of small floating boards, air mats and floating games, instruments which represent stimulating support for the autistic subject. The sessions were divided into two phases; the first relating to the discovery and introduction of the aquatic facility (pool, water depth, pool side, locker rooms), introduction to the water element and guided exploration, first approaches to floating and phase regarding respiration and apnea.

The second phase occurs when the subject has reached a good level of security in the water and autonomy, has been passed into the deep pool, guided by the instructor who taught him supine and prone slides, propulsive forms, the different ways to move in the water and the different style techniques.

The instructor has also been careful to create an environment rich with trust and ease through reassuring tones of voice, expressions and movements.

To verify and evaluate the course of each single subject questionnaires with predefined descriptors relative to the motary and social effectiveness were given: these questionnaires were filled out at the beginning and at the end of the course by each instructor and by three teachers from the school attended by the subjects. Each area is made up of an item to describe the different types of behavior and the eventual differences from the beginning to the end of the activity. Specifically, the instructors were faced with two tests for each subject regarding motary learning and social affective; the teachers (three from different learning areas for each subject) a questionnaire regarding the socialization and curricular learning; families were given a questionnaire regarding autonomy, emotions and family interaction.

\section{Results}

The data collected through the systematic observation and with the questionnaires give to the instructors, the teachers and the families, shows that subjects appear more independent, use the floating board more naturally, dive and have gained great interest for shiny floating objects; in the area regarding social effectiveness, the most relevant figure is that all have accepted physical contact, interacting with their peers. 


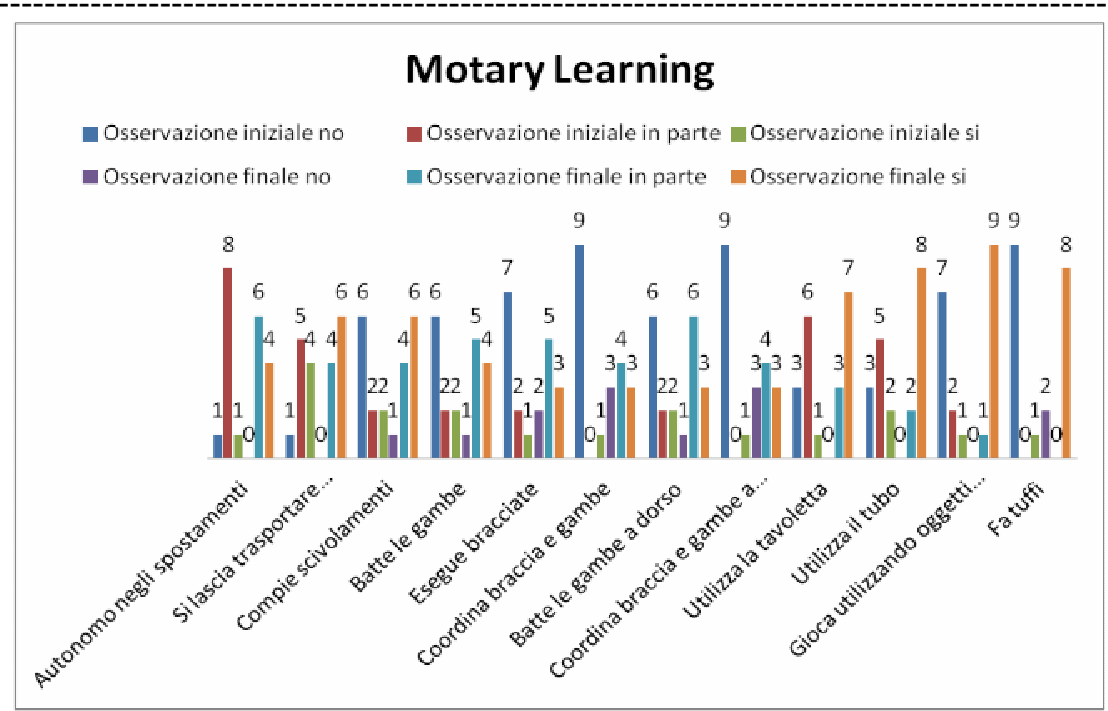

Figure 1-Motary Learning

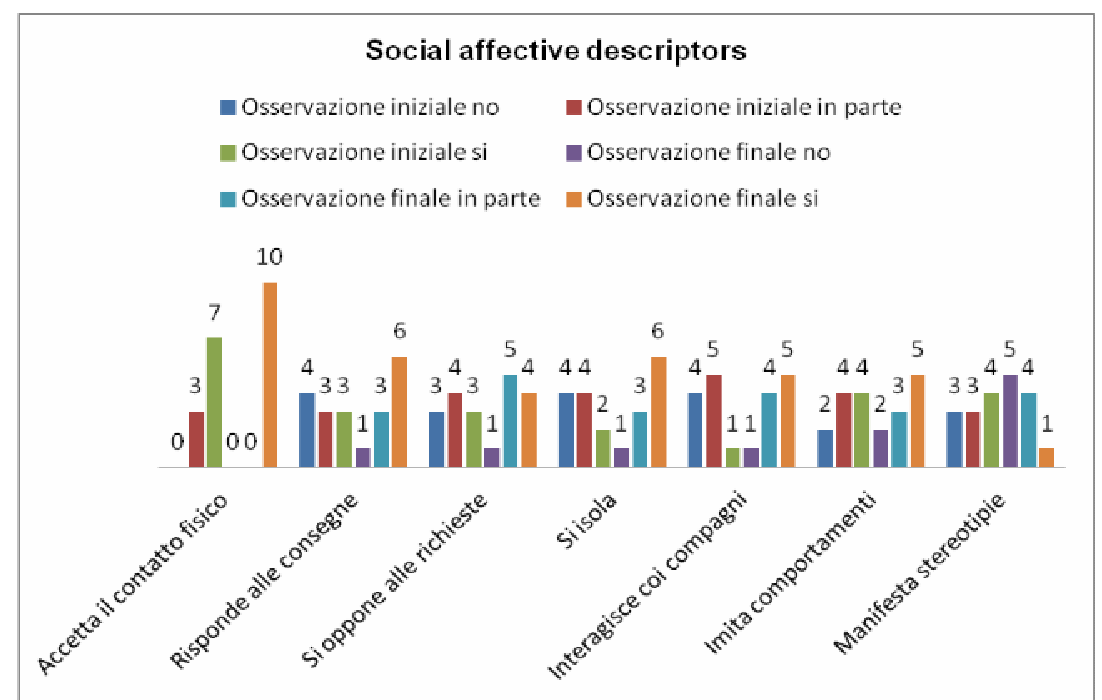

Figure 2 - Social affective descriptors

The same results emerge from the teachers' questionnaires, confirming those resulting from the others, stating that the subjects are more able to express their emotions and feelings; perceptive and cognitive difficulties have also diminished.

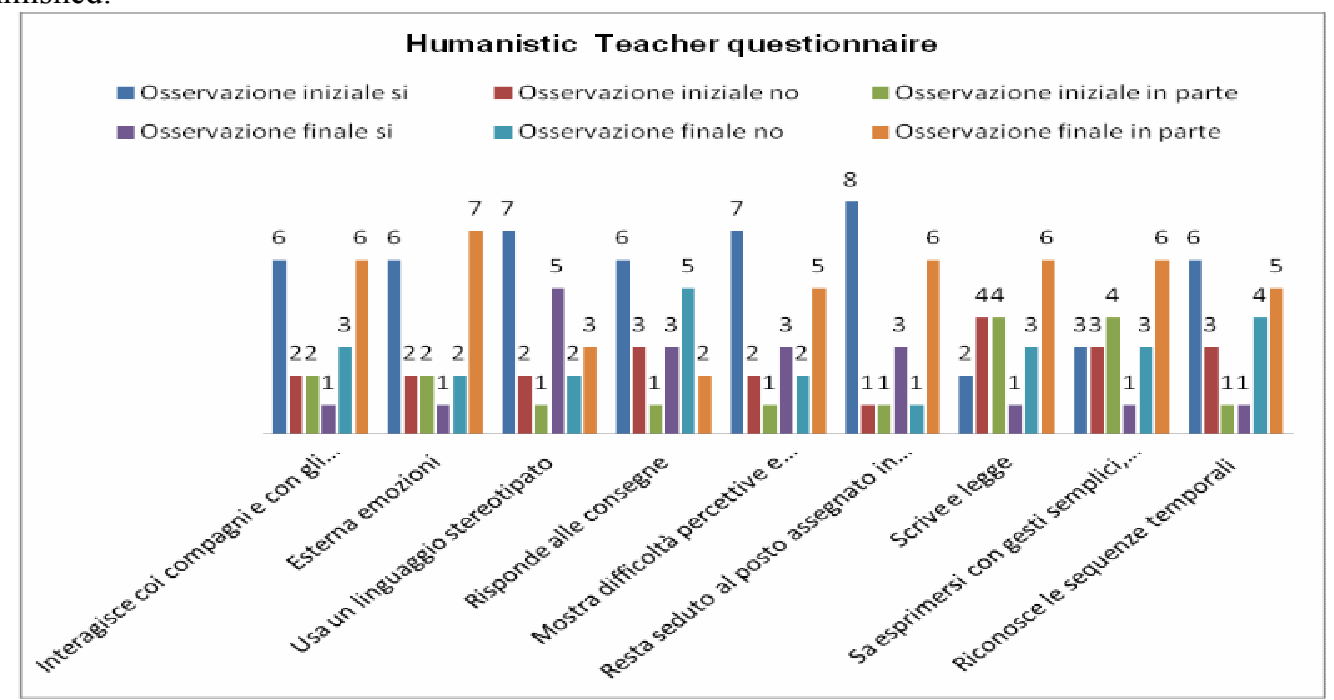

Figure 3 - Humanistic Teacher questionnaire 


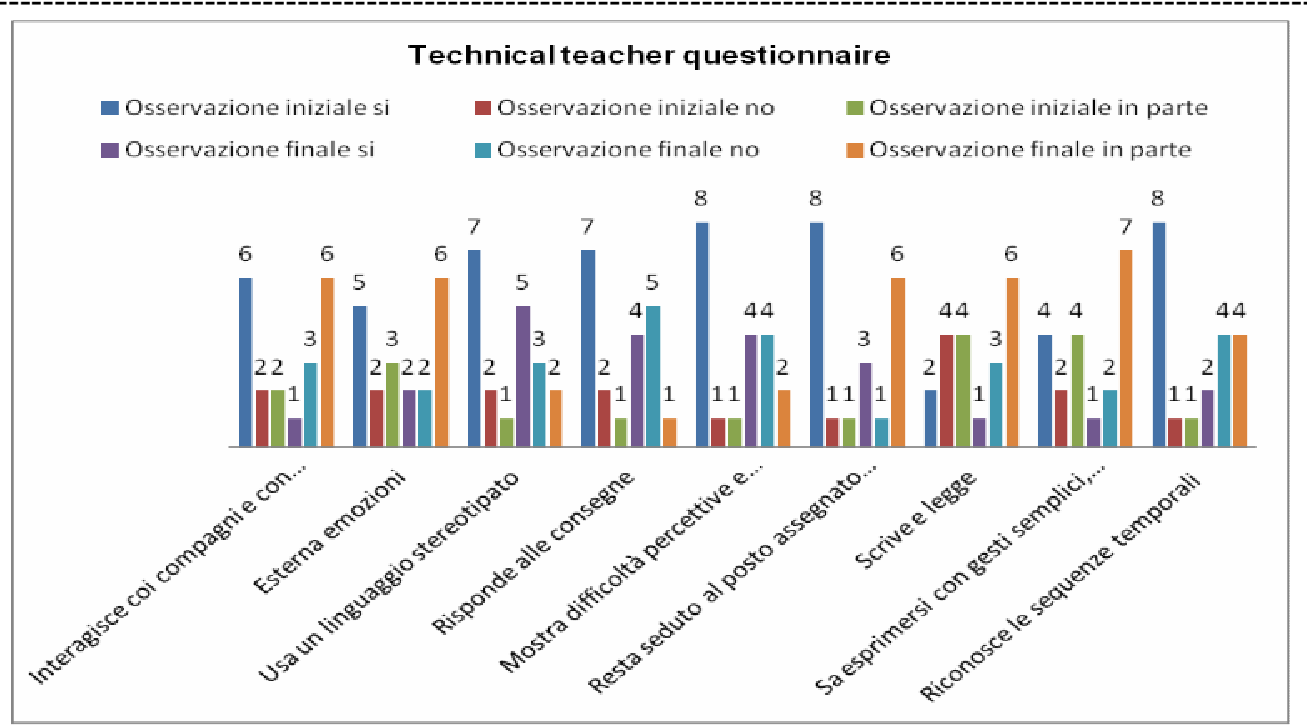

Figure 4 - Technical teacher questionnaire

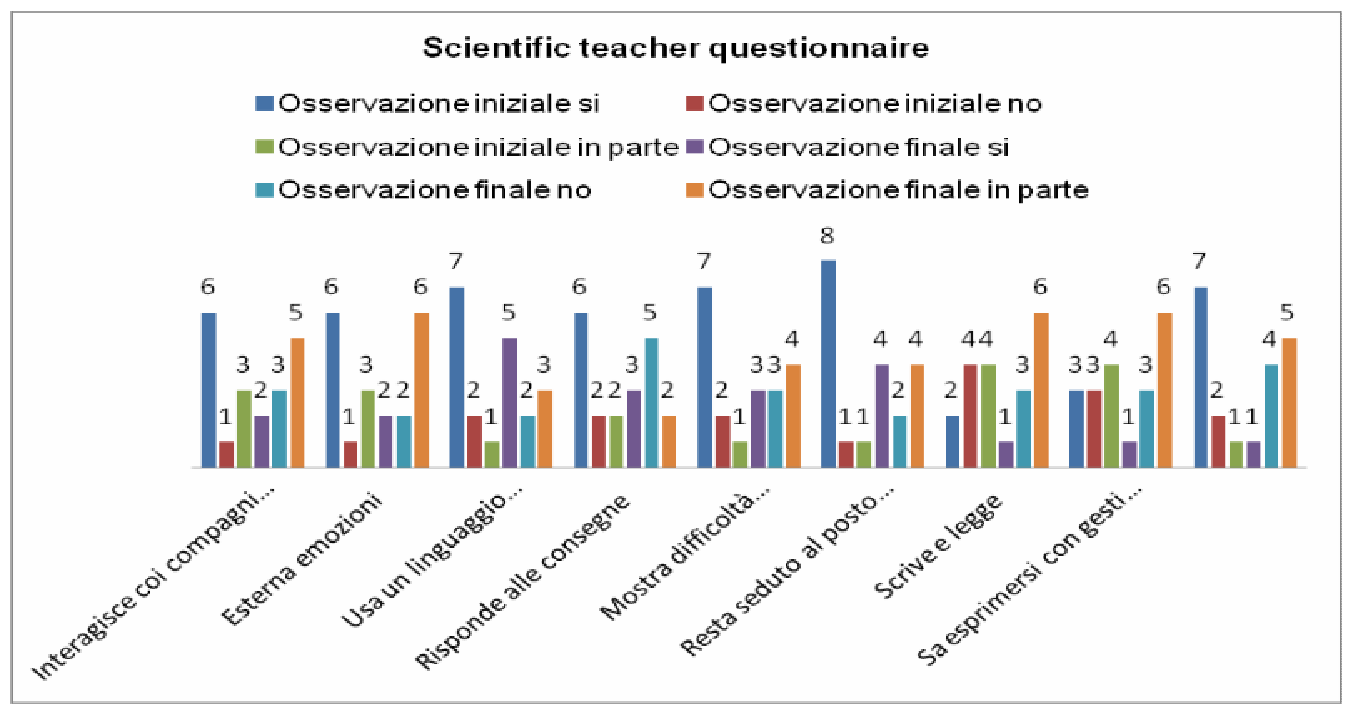

Figure 5 - Scientific teacher questionnaire

Regarding the family, the most evident data regards heightened independence, improved interaction with family members with which emotions are expresses.

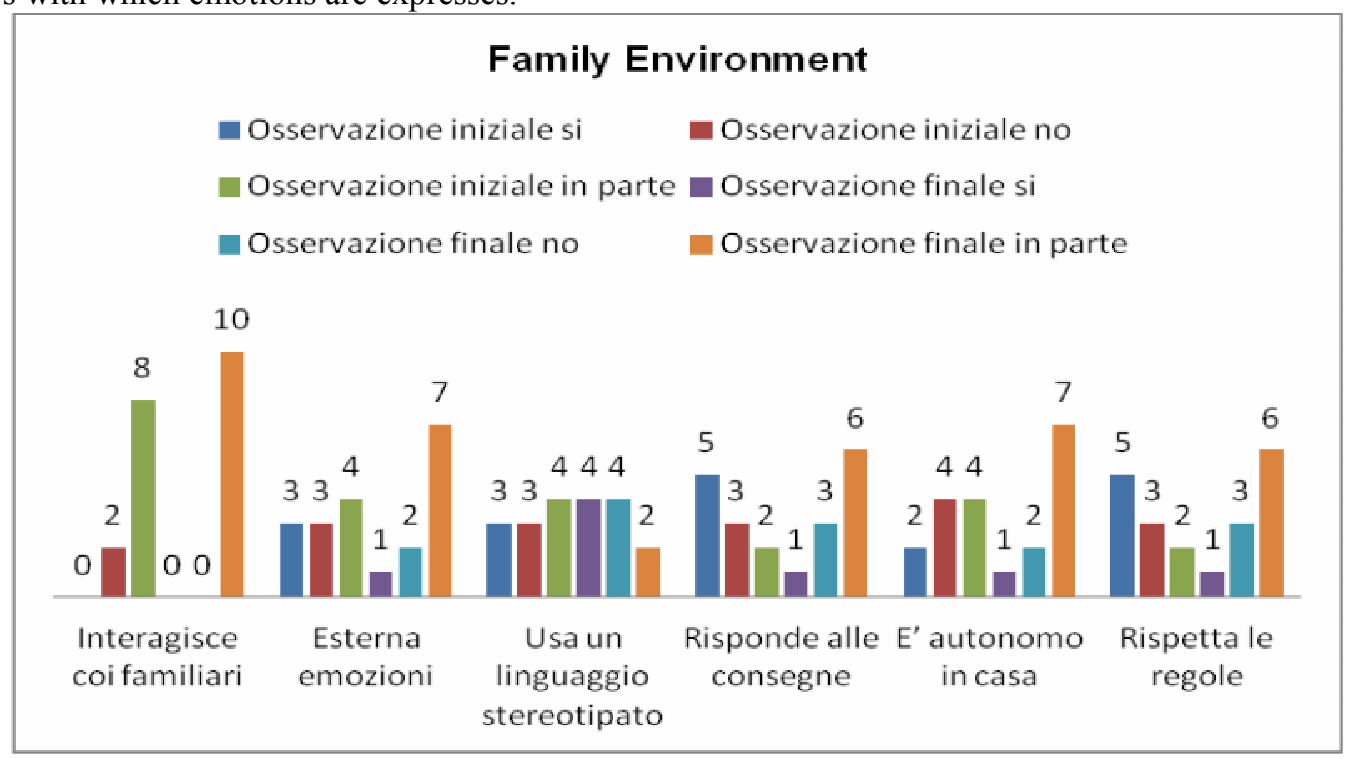

\section{Discussion and conclusion}

Figure 6 - Family Environment

Swimming activities, thus, consider an improvement in the subjects involved, especially from the social and emotional stand point, personal independence (domestic activities-social, free time), in the organization of 
time in everyday life, in the classroom and outside the classroom, more interaction in group classes, notable improvement in scholastic and communication ability, learning principle fundamentals (reading/writing/calculations) and learning scholastic subjects (highly functional subjects), can be considered a valid instrument to favor the insertion and the inclusion of subjects with autism in all social environments. Comparing the data collected, and considering the three different aspects of the subjects' lives, with adults and with peers (this appears with a final figure plainly higher than the initial figure) an independence: this confirms that interaction and the ability to live interacting with others in different environments represents a fundamental factor in learning.

\section{References}

Tursi D, Napolitano S., Raiola G., 2013, Assessment the technical execution in archery through video analysis .Buletin Stiintific - Universitatea din Pitesti. Seria Educatie Fizica si Sport, vol. 17; p. 41-43, ISSN:14531194, doi: 10.7752

Napolitano S., Di Tore P A, De Miro C, Raiola G., 2012, TECHNICAL ANALYSIS IN HIGH DIVING. Buletin Stiintific - Universitatea din Pitesti. Seria Educatie Fizica si Sport, vol. 16; p. 96-99, ISSN:1453-1194, doi: 10.7752

Napolitano S., 2014, Cliff diving: water impact and video-analysis. Journal of Physical Education and Sport, vol. 14; p. 93-97, ISSN: 2247-8051, doi:DOI:10.7752/jpes.2014.01015; C) JPES

Tursi D, Napolitano S, Di Tore P A, Raiola G., 2012, Evaluation of influence of ball handling on swimming intensity in female water polo. Buletin Stiintific - Universitatea din Pitesti. Seria Educatie Fizica si Sport, vol. 16, p. 99-103, ISSN: 1453-1194, doi: 10.7752

Tursi D, Napolitano S, Raiola G., 2013, Assessment the technical execution in archery through video analysis . Buletin Stiintific - Universitatea din Pitesti. Seria Educatie Fizica si Sport, vol. 17, p. 41-43, ISSN: 14531194, doi: 10.7752

Napolitano S, Tursi D ., 2013, The evaluation of the tactic in women's water polo: the experience of a team in the Italian championship premier league. Buletin Stiintific - Universitatea din Pitesti. Seria Educatie Fizica si Sport, vol. 17, p. 36-40, ISSN: 1453-1194, doi: 10.7752

Raiola g, Parisi f, Napolitano s., 2014), Sports skills in youth volleyball by video analysis teaching method. Procedia: social \& behavioral sciences, vol. 117; p. 436-441, issn: 1877-0428

Tursi d, napolitano s., raiola g., 2013, Assessment the technical execution in archery through video analysis . Buletin stiintific - universitatea din pitesti. Seria educatie fizica si sport, vol. 17; p. 41-43, issn: 14531194, doi: 10.7752

Napolitano S., Di Tore P A, De Miro C, Raiola G., 2012), Technical analysis in high diving. Buletin stiintific universitatea din pitesti. Seria educatie fizica si sport, vol. 16; p. 96-99, ISSN: 1453-1194, doi: 10.7752

Filipek PA et AA. Neurology 22 August 2000, pp. 468-79

Folstein S., Rutter M: Infantile autism: a genetic of 21 twin pairs. - Journal of Child Psychology and Psychiatry $18,297-321,1977$ 